\title{
Federalism and Contending Issues in Contemporary Nigeria: Mapping Alternative Perspectives for a Neo-Federalist Paradigm
}

\author{
Joseph Okwesili Nkwede $^{1}$, Kazeem Oluwaseun Dauda ${ }^{2} \&$ Olanrewaju A. Orija $^{3}$ \\ ${ }^{1}$ Department of Political Science, Ebonyi State University, Abakaliki, Ebonyi State, Nigeria \\ ${ }^{2}$ Department of Political Science, Tai Solarin University of Education, Ijagun, Ogun State, Nigeria \\ ${ }^{3}$ Department of Political Science, Obafemi Awolowo University, Ile-Ife, Osun State, Nigeria \\ Correspondance: Kazeem Oluwaseun Dauda. Tel: 234-80-5466-9156. E-mail: seundelaw@gmail.com
}

Received: September 11, 2018

Accepted: September 22, 2018 Online Published: September 28, 2018

doi:10.5539/ass.v14n10p111

URL: https://doi.org/10.5539/ass.v14n10p111

\begin{abstract}
Evidence abound that Nigeria's form of federal system has been grappling with serious working and institutional challenges. The paper interrogated contending issues ravaging Nigeria's federal polity with a clarion call for timely adoption of neo-federalism paradigm. It employed qualitative research method with classical model of federalism as framework of analysis. The paper established that Nigeria's federal republic is associated with over-concentration of governmental powers at the centre, sectional domination of powers and political leadership, inept and corrupt leadership/bad governance, socio-economic crisis, insecurity, corruption, favouritism and nepotism, problem of power sharing and poor implementation of federal character principle, which further heightened the delivery of socio-economic services and democratic dividends to the people. It concluded that for Nigeria's federation to stand the test of time and overcome myriad problems it is currently facing, embracing the neo-federalism paradigm is inevitable. Among recommendations proffered include devolution of powers, adequate provision of sustainable security, and election of dedicated, committed and visionary leadership at all levels of government with the ability to drive the economic blueprints of this nation towards greatness, provide essential needs for the citizenry and promote good governance.
\end{abstract}

Keywords: federalism, governance, insecurity, leadership, neo-federalism paradigm

\section{Introduction}

Consequent upon criticisms leveled against the 1922 Clifford's Constitution, Nigerian State wore a toga of federal-pattern style following the provisions for the Central Legislative Council and regional Legislative Councils in the Richard's Constitution (1946) based on Bourdillon's erstwhile recommendations, and progressive recognition of the Central and Regional governments in Macpherson's Constitution of 1951. The emergence of new government with new grundnum, that is, Lyttleton's Constitution (1954), paved way for the adoption of a true federal form of government, where distinct governmental powers are shared between the Central government and the Regional governments (Awofeso, 2014). In line with the federal philosophy, Nigerian State has evolved to be structured into Federal Capital Territory (FCT) Abuja (centre), thirty-six (36) States clustered into six geo-political zones of the North-east, North-west, North-central, South-south, South-east and South-west, and divided into 774 Local Government Areas (LGAs) as entrenched in the 1999 Constitution (as amended). It is evident, however, that the practice of federalism since independence in 1960 has been conflict-prone with incessant clamour for a 'true federalism'.

However, the last decade has witnessed renewed vigour towards clamouring for a restructured federation by some public affair analysts, politicians, and government functionaries, scholars of repute, legal professionals, religious leaders and notable Nigerians. These imply that the structural configuration of Nigeria needed urgent revisiting, renegotiation and restructuring. The structural imbalance of Nigerian federation is believed to have compounded the socio-economic development and governance crises limiting her potentiality of becoming one of the twenty emerging economies in the world by the year 2020. Consequently, socio-economic and political convulsion facing the polity in contemporary times have continued to threaten the actualization of true federalism as espoused by $\mathrm{KC}$ Wheare and subscribed to by founding fathers of Nigerian state in pre-independence period. This situation, without doubt begs for scholarly devotion and interrogation. The 
objective of this paper therefore, is to unravel contending issues ravaging Nigerian federalism in contemporary period taking into cognizance the alternative perspectives for neo-federalism.

\section{Conceptual Clarifications}

There exist various conceptions on federalism in extant literature. We shall however consider few of these viewpoints here for our proper understanding. The term "federalism" connotes different thing to certain individuals. The concept, according to the father of federalism, KC Wheare (1963), is the method of dividing powers in so that the general and regional units are each within a sphere co-ordinate and independent. In the words of McLean and McMillan (2003: 195), "federalism suggests that everybody can be satisfied by nicely combining national and regional interests within a complex web of checks and balances between a national or federal government, on the one hand, and a multiplicity of regional government, on the other". Similarly, Enu, Opoh and Bassey (2017: 73) describe federalism as a "system of government whereby governmental powers and economic structures of a country are shared between Central government and component federating units".

Federation describes any country that embraces federal ideology. Dicey defined a federation as a political contrivance intended to reconcile national unity and power with the maintenance of state rights. To express it in the view of Wheare (1963), federation is the group of states or communities desire to be united, but not to be unitary. Kapur (2006) identifies basic features of a federation to include the desire for union, the will to lose sovereignty by the states involved as soon as a federation is formed, mechanism of two parts (Central and Regional governments), written and rigid constitution, supremacy of the constitution and permanency. To Kapur, a federal state or polity envisages a dual government of divided powers. In a nutshell, federalism implies a philosophy, methodology, principle or theory that describes how a plural state should be governed, governmental powers shared, and inter-governmental relationship among sovereign states maintained.

Following from the foregoing, it can be deduced that federalism is a distinct principle of governing a state hitherto with different governing style and administration. It represents a system of government that describes a method of arranging territorial government, and accommodating differing territorial interests that, at one and the same time, avoids perceived over-centralization of governmental powers at the centre. This is corroborated in Kincaid's (1995) conception of federalism as the approach to governance that seeks to combine unity or shared rule with diversity or self-rule. Federalism, with its division of powers between the Central and federating units is, as Friedrich (1968: 216) says, "a mainstay of constitutional government."

\subsection{Theoretical Framework}

The paper is anchored on classical model of federalism. Classical model of federalism is associated with Kenneth Clinton Wheare (1907-1979). Wheare is often referred to as father and doyen of federal philosophy. K.C. Wheare argued that a system can only be said to be Federal if there is "a division of powers between one general and several regional governments, each of which, in its own sphere, is co-ordinate with the others; each government must act directly on the people; each must be limited to its own sphere of action; and each must within that sphere, be independent of the others" (Wheare, 1963, p. 11). Looking at Wheare's classical idea of federation, it can be deduced that both the legal and institutional mechanisms must be put in place before a decision to federate. To achieve strict division of powers capable of ensuring total independence and coordination between the central and component units, written and rigid constitution must be in existence. As such, the Constitution is supreme in a federal polity. This is maintained by Kapur (2006: 403) that "unlike the unitary government, powers of the units in a federation are original and not derived. They are not the grant of the central government, but the gift of the Constitution and as such they are constitutionally protected."

Flowing from the above argument is the fact that in a true federal system, both the central and regional governments are coordinate, independent authorities within their allotted sphere of jurisdiction. Neither one can encroach upon the powers of the other. If any change is desired to be made in the distribution of powers, it cannot be made by any one of the two sets of government alone. It must be made by amending the Constitution as prescribed by law. Also, it means equality of status between the two sets of government and this is one of the cardinal principles of a federal polity. Federalism also demands that each component units are free to run their own administration and participate in the federal government. Equally, a federation depends upon the consent of the people. This is where the concept democracy comes in, depicting that a federal state must be a democratic state.

As argued by Mackintosh (1962), the Nigerian federation has always had peculiar features; the most evident being that it was not created by the coming together of separate (confederal) states but was the subdivision of a country which had in theory been ruled as a single unit. Nigeria had at one time a "civilian federalism" and sometimes "military federalism", and each has given Nigeria federalism different shapes and structures (Sagay, 
2003). Without doubt, the incursions of the military juntas in Nigerian governance turned the whole idea of federalism to a "hard row to hoe". Little wonder then did Muhammad (2007: 189) asserts that "Nigeria's adoption of the federal system was not as a strategy to manage problems of pre-independence period but more importantly as an enduring strategy that would help detonate a major source of threat to the future political stability of an independent Nigeria."

Since independence, Nigeria federation has been confronted with varied crises that have continued shaking the foundation of the country's unity and corporate existence. The dimensions of these crises include electoral crisis, intra/inter-party crises, crisis over resource sharing/control, inter-ethnic struggles, boundary disputes, religious uprising/extremists' deadly attacks, insurgency, and terrorism. Chiefly among these is governance crisis identified as the root of all evils associated with African states, Nigeria being inclusive. All these crises have culminated to be the major reasons of agitation for restructuring of Nigerian federation in the past years.

\section{Methodology}

The paper adopted qualitative research method. Qualitative research method, as argued by Hancock, Ockleford and Windridge (2009), is concerned with developing explanations of social phenomena aimed at helping us to understand the world in which we live and why things are the way they are. This method is suitable for this paper because it enables readers to understand the current Nigerian situation through a holistic perspective. However, the paper which derived its argument from existing secondary sources of data including textbooks, journal articles, newspapers, government publications, constitutions, and Internet, is content, theoretically and discourse analyzed.

\section{Federalism and the Nigerian State}

Prior to the amalgamation of the Colony and Southern Protectorate with Northern Protectorate in 1914, the current geographical entity called "Nigeria" with geo-political zones and states were once conglomeration of "empires", "emirates", and "kingdoms", that are previously autonomous political entities and sovereign within their spheres of jurisdiction in conformity with their socio-cultural, political and economic realities. These entities relate with one another diplomatically, economically, politically, socially, and culturally. They equally had their own unique ways of political administration, administration of justice, and conflict mediation, conciliation and resolution processes. In the words of Awofeso (2014: 16), "all the functions of modern day government were performed by some kind of rudimentary, non-differentiated and non-secularized structures which cut across different levels of administration. Laws were made, executed and adjudicated". Decentralized, semi-centralised and centralised political administration could be identified within the Igbo, Yoruba and Hausa/Fulani political systems, respectively. This actually presents the ways and manners in which the pre-colonial Nigeria was administered.

Following the official conquest and annexation of Lagos in 1861, colonial rule was established in Nigeria. Since 1900 when the British government decided to take full charge of the administration of the entire country, the Colonial government had gradually embarked on progressive amalgamation policy in the country. Hence, the British government divided the entire country into three administrative units - the Northern Protectorate, the Southern Protectorate and the Lagos Colony in 1900, two administrative units - the Protectorate of the Southern Nigeria and the Colony, and the Northern Protectorate in 1906, and then into a single unit of administration in 1914 (Awofeso, 2014).

The amalgamation of 1914 brought with it new grundnum for which the exercise of powers are spelt out and entrenched, that is, the Lugard's Constitution (1914). Despite the introduction of more sophisticated Constitution in 1922, it is imperative to note that not all regions were represented in the Legislative Council. The unnecessary exclusion, marginalization of certain sections of the country and Europeanization of the Order-in-Council, Legislative Council and Executive Council, led to bitter struggles, agitations and increase in tempo towards the formation of a new government. The new government headed by Sir Arthur Richardson came into existence with the Richard's Constitution (1946) which provided for regionalism as against Unitarianism earlier adopted. The 1946 Constitution which aimed at promoting unity for the diverse elements made up the country provided the groundwork for eventual evolution of federalism in Nigeria. The Macpherson's Constitution (1951) improved upon the Richard's Constitution by introducing quasi-federalism. This implies that greater autonomy was given to the various regions.

The Lyttleton's Constitution (1954) introduced true federalism in Nigeria. By this, greater autonomy was provided to various regions thus giving room for functional division of powers between the Central and Regional governments. Subsequent constitutions including the current 1999 Constitution (as amended) professed the ideals of federalism. For instance, section 2(2) and section 3 provide that Nigeria shall remain a federation 
consisting of 36 States and a Federal Capital Territory. The Constitution also recognizes 774 Local Government Areas, and divides powers among these levels of government on the basis of Exclusive, Residual and Concurrent Lists. The Exclusive List is within the authority of the national government to carry out, e.g. foreign affairs, defense, etc. On the other hand, the Concurrent list is within the responsibility of the Federal and State government, while the Residual list is exclusively within the responsibility of the State government. But in a situation where there is a conflict between the state and that of the national government, the national power will always supersede the state power.

\subsection{Contending Issues and Trends of Nigeria's Federal System of Governance}

Although federalism is reputed to be an effective political cum constitutional design for managing complex governmental problems usually associated with ethnic and cultural diversity (Ojo, 2002), it has been very vulnerable to wanton destruction of lives and property, breakdown of law and order, and instability/crisis in Nigeria. There are many unresolved issues associated with Nigeria federalism in contemporary time such include over-concentration of governmental powers at the centre, sectional domination of powers and political leadership, inept and corrupt leadership/bad governance, socio-economic crisis, insecurity, corruption, favouritism and nepotism, problem of power sharing, and poor implementation of federal character principle. These fundamental issues and trends of Nigeria's federal system in contemporary period, form the crux of this section.

\subsubsection{Over-concentration of Powers at the Centre}

It is crystal clear that what currently practicable in Nigeria is over-concentration of powers at the Centre as against the philosophy of a true federalism. Federalism presupposes autonomy of each tier of government, which means that both the State and Local governments must be independent of the Central government in terms of powers (legislative and judicial), finance, appointment, etc. This essential element of a Federal state is found wanting in Nigeria. This challenge has been programmed to remain so as reflected in the Nigeria's 1999 Constitution. The submission made by Nkwede (2013: 76) is apt in this regard:

The components of the federation - the states today, depend almost entirely on the centre for security, finance, roads, schools, health facilities, power, employment, water, industries, etc. The situation is so pervasive such that if the centre delays in releasing funds due to the states to them, there is tension, chaos and doubt because the states cannot even pay salaries, let alone prosecuting their development programmes on their own.

Incontrovertibly, smaller units (States and Local) of government in the present Nigeria lack requisite power, geographic span of control, and knowledge of resources, to cope with inescapable issues related to economic stability and development, and are unable to assume satisfaction of basic needs and broadening wants, not to be neglected in the age of the common man. This is to the detriment of effective governance and development of these federating units. Corroborating this argument, Atiku cited in Vanguard Editorial (May 31, 2016) laments that the Federal government is too big and powerful relative to the federating units. An excessively powerful centre does not equate to national unity and integration. This situation needs to change.

\subsubsection{Sectional Domination of Powers}

Sectional domination of powers and political leadership in Nigeria cannot be ruled out. It is vividly clear from available evidences that the motive behind the division and eventual amalgamation of the separate unit of ethnic groupings and political entities was not intended to serve the national interest; rather it was meant to nepotise sectional interest. This is elaborately pointed out in the observations made by Falola and Heaton (2008: 117), as thus:

The ostensible reason for amalgamating the Nigerian Protectorates was economic...the economy of the Northern Protectorate had floundered under indirect rule and had not become fully self-financing as of 1914. Taxation had not produced enough revenue to cover the administrative needs of the Protectorate, and commerce had not grown sufficiently to make the region profitable. To finance itself, the Northern Protectorate relied on annual subsidies from Southern Nigeria and an imperil grant-in-aid from the British government to the tune of approximately $£ 300,000$.

Fast forward to independence, the Northern hegemonic domination was argued to be responsible for the first military coup in Nigeria in 1966 (Bassey, 2012). It is unimaginable trend that out of fifty-seven (57) years of Nigeria's political independence, the North had ruled the country for over 35 years, while the South altogether had ruled only for about 22 years. Moreover, the North has 19 States, while the South possesses 17 States. In the distribution of head of ministries, security chiefs and so on, the North curry majority. The implication of this is that other ethnic groups and regions have been made subservient to the Northern region since inception till date. 
Its consequent effect is the emergence of series of ethnic militants armed with the purpose of standing against the injustice for being short-changed in the distribution and allocation of powers and resources.

\subsubsection{Influence of Governing Elites/Cabals}

The influence of governing elites/cabal on Nigerian government and politics is incontrovertible. Elites are those who wield political, economic, social and ethno-religious influence or other powers in a country (Dauda, 2017). This dominant class or powerful cabal or ruling elites, as observed by Therbon cited in Melendez (2016), not only install particular regime, they also influence state policies for their own benefits. These are who Prof. Pat Utomi in his article titled: "Healing a bleeding nation" (2017), describes as "club of capture". Utomi then grouped this club into three, namely: modernizer wannabes (those who the value system sabotaged their desire), narcissistic influencers (those who are consumed by their self-love; are contented with whoever is in power so far they can appoint the oil minister and others), and entitlement-minded ones (those who believe that Nigeria is their property and are entitled to the sharing of its resources) (Toluwani, 2017).

Utomi further attributed Nigeria's woes including underdevelopment and institutional failures to this set of people. This set of people who enjoy larger share of national cake, always do everything within their powers to ensure their hegemony within their respective occupied elective offices, which often results to do-or-die affairs with consequence on electoral outcome. Their mischievous acts have downplayed the achievement of good governance and development, and hinder true federalism to flourish. In tandem with the above assertion, Eze, Nkwede and Uwabunkonye (2012) argued that politics and power relation in Nigeria are always determined by few individuals among the Nigeria elites who belong to various regions, ethnic enclaves and sections. And that politics and power relation always directed towards overshadowing of the masses from the political economy of the nation.

\subsubsection{Inept/Corrupt Leadership and Bad Governance}

Perhaps the most compounding woe betiding the Nigerian state since independence remains that of inept/corrupt leadership and bad governance. Both remain the bane of development and governance crisis in Nigeria. A government is elected to solve problems and improve the lives of its people, (Adenikinju, 2016) hence this seems inapplicable to Nigerian leaders. Various writers have emphasized on how Nigeria has been unlucky in having good, diligent and sincere leaders (Lawal \& Dauda, 2016; Ali, 2013; Achebe, 1983). The resultant effects are failure to deliver good governance and securing welfare of the people. Hence, lack of effective and visionary leadership in Nigeria is the greatest cause of lack of direction, unity and cohesion required for democratic sustenance, good governance and national development (Akinola, Adebisi, \& Oyewo, 2015).

\subsubsection{Socio-Economic Crisis}

No doubt, Nigeria at the moment is in 'state of flux' where poverty rate is on the increase, unemployment level on the rise, and economy is in comatose, while hardship and rife in inflation have become a daunting challenge (Dauda, 2017). As of January 1, 2016, the population of Nigeria was estimated at 184.635 million. Out of this figure, about one hundred and ten million (110 million) people was said to be poor and about two-tenth are in extreme poverty (Adetayo, 2016), while 28.58 million (14.2\%) people were unemployed as at December 2016 (Vanguard Editorial, June 6, 2017). The above figures seem appalling and awful of the nation blessed with abundant human and material resources. Recently, the International Monetary Fund (IMF) warned that the Nigerian economic growth rate may shrink further and that inflation remains a potential problem (Adenikinju, 2016). Undeniably, the nation's economic crisis has deepened.

\subsubsection{Insecurity and Political Instability}

Without mincing word, insecurity and political instability have been the permanent features of Nigeria body-politic. Nigeria has been crisis-ridden since the attainment of political independence in 1960. From the first military coup in 1966 till their last interregnum in 1998, the Civil War of 1967-1970, various electoral violence, ethnic agitations for states creation and against marginalization, and ethno-religious crises. In the recent times, for instance, the waning insurgent attacks by boko haram sect in the North-east, Fulani-herdsmen conflicts in the North-central, bombing and militancy attacks in the South-south, kidnappings in the South-east, and ritual killings, cultism and recently kidnapping in the South-western region portend danger to the process of nation-building, political stability and national cohesion.

\subsubsection{Corruption, Favouritism and Nepotism}

Corruption, favouritism and nepotism have remained cantankerous issues responsible for poor management and administration in Nigerian public and private sectors. Since the substantial portion of the national revenue is controlled from the top (i.e. federal/central government) and this exercise is often characterised by corruption, 
while the award of contracts, appointments and promotions, as well as other benefits rather done in a transparent manner and follow due process, are often influenced by favouritism and nepotism. Corruption remains a major contributor to national disunity and instability in Nigeria. In this sense, Osuntokun (2016) points out that ethno-regional parochialism and over-centralised government is the root of public corruption in Nigeria. He states further that the abuse of office, favouritism and political nepotism have been part of government since independence.

\subsubsection{Resource Control and Sharing Formula Crisis}

Crisis on resource control and sharing formula are another factors affecting the effective working of federalism in Nigeria. There has always been crisis in lieu of the control and management of resources from the jurisdictions of states or local governments such resources are extracted since independence till date. No doubt resource control has remained the most contentious issue among the three tiers of government. Nigeria operates a system in which the federal government harnesses the natural resources and shares revenue with the states and local governments, which is a departure from an ideal federal system, in which the regions or states as the federating units control resources located in their territories (Dickson \& Asua, 2016; Agbaje, 2013). Adelegan (2009), while subscribing to the problem of sharing formula in Nigeria, argues that the unrests and widespread disturbances in many parts of the federation are attributable to issues of fiscal federalism which must be thoroughly and critically examined within the context of federalism. In a similar vein, Nkwede, Nwali and Orga (2013) stated that one of the greatest challenges of federalism in Nigeria is that of sharing formula as regards to the fiscal resources generated and jointly owned by the federating units.

\subsubsection{Poor Implementation of Federal Character Principle}

Another disturbing issue is poor implementation of federal character principle in all ramifications. Federal character principle as a strategy adopted to allay the fears of domination and marginalization of some ethnic groups in Nigeria, has failed to prevent tribal or regional dominance of any government, its institutions and agencies. This is in concurrence with the report in Sunday Tribune (July 16, 1995: 5), that the principle "has been used to achieve unintended purposes of ethnic-cleansing sort-of". In actual fact, federal character policy instead of promoting "fair and effective representation of the various components of the federation in the country's position of power, status and influence" (Government's views and comments on the Findings and Recommendations of the Political Bureau (1987: 86), it rather engenders instability and national disintegration. Observing trend shows that appointments into key offices are not evenly distributed, as these are often dictated by the whims and caprices of the political elites.

From the foregoing, the fundamental issues analysed in this section depicts that the trend of Nigeria federal system is tilting towards destruction. With these disturbing trends, Nigeria may stand the risk of democratic recession, another civil war and probably division. It may be difficult for a country such as Nigeria to toe the path of integration or stability. It is imperative for all stakeholders to concentrate more on how to manage the present Nigeria's federal structures towards ensuring national unity and integration, stability and development, rather than promoting superfluous division and disintegration.

\subsection{Managing Nigeria's Federal Structures Towards Enhancing Good Governance, National Integration and Development: Mapping Out Alternative Perspectives}

No doubt, the philosophical foundation upon which federalism is laid has the tendency and serves as a viable option for national unity and integration, as well as platform for good governance. Federalism is considered an effective way of achieving and preserving both integration and stability in deeply divided societies. Duchacek (1977) argues that the dialectic and disparity between the geographic confines of territorial states on the one hand, and the boundaries of ethno-territorial communities on the other, seem to invite a federal solution. Similarly, Macmahon cited in Osaghae (1984) contends that, federalism is a means in countries where diversity is pronounced, and the consent of the governed are accommodated by the government.

However, Nigerian federalism in various writings has been described as "weak", "fragile", "convoluted" and sometime "failed". Thus, managing Nigeria's federalism has been a daunting challenge to post-independence governments. Quite a number of strategies put in place by successive governments to manage federal structural imbalance seemed to have yielded diminutive successes. Some of these efforts include the creation of states (36 States), adoption and establishment of National Youth Service Corps scheme (1973), introduction of a uniform local government system (1976), establishment of Federal Character Commission and adoption of federal character principle (1978). Others include the relocation of Federal Capital Territory to Abuja (1991), introduction of revenue sharing formula, creation of Niger Delta Development Corporation (NDDC) (2000), and establishment of Unity schools, among others. These measures, as argued by scholars and analysts, have not 
worked adequately to promote Nigeria's national unity and integration (Enu, Opoh \& Bassey, 2017; Atiku, 2016; Nkwede, 2013; Bassey, 2012; Ojo, 2009), hence, the proposition of the Neo-federalism paradigm as the solution to Nigeria's intimidating challenges.

The Neo-federalism paradigm is a model which prescribes a paradigm shift from what is currently obtained to a more desirable decentralization of political powers, allocation, transformation and utilization of resources, fiscal powers, development, laws and functions. It deals with "what it ought to be" as against "how it should be". The Neo-federalism model is a political philosophy of devolution, or the transfer of certain powers from the Central government back to the states. Exponentially, the paradigm involves repackaging, re-branding and restoration of federal ideology to a unique Wheare's philosophy and conditions for a true form of federal system, such that, each level of government are independent with distinct constitutional division of powers, financial autonomy for the levels of government, and that, none of the government will be seen as inferior. The practice of federal ideology in Nigeria, in contemporary time, is devoid of the above conditions and as such needs to be revisited.

In light of the above position, it is no longer news that the Nigerian Constitution recognizes three levels of government with the Central (federal) government at the apex followed by the State governments (36 in number) and then Local government (numbering 774). This shows that Nigeria is a federal state. However, the analysis of the issues in Nigerian federalism has shown that there is crisis with the practice of this form of government since 1960s. The paradigm suggests that there is need for restoration to the States, of some of the autonomy and powers, which they have lost to the Federal government as a consequence of military incursion into Nigerian politics. It further defines the devolution of powers through constitutional reform that is aimed at making each level of government independent. This means that the Federal government should not be so dominant in the decisions affecting the whole nation.

The above contention is in tandem with Vile's (1961: 197) position on federalism that, "in this system a balance is maintained such that neither level of government becomes dominant to the extent that it can dictate the decision of the other, but each can influence, bargain and persuade the other". In line with this perception, Falana cited in Oyetunji and Ramon (2017) avers that devolution of powers, in the Nigerian context, means that the Federal Government will be in charge of defence, foreign affairs, immigration, inter-state commerce, fiscal and monetary policy, etc, while the States will manage their own affairs and develop at their own pace. Devolution of powers and Local government autonomy remain important elements of a true federalism. Going by this argument and highlighting the relevance of devolution of powers to the constituent units, Okotie (2010: 15) asserts that:

Devolution is associated with local autonomy and with increase scope for popular participation in governmental activities. Under the devolution category, local governments are granted powers to source for their revenue control, their finances as well as recruit their own personnel. Devolution indicates status and policy making power. Devolution of power is also designed to create a political environment in which power to access political, economical and social resources is distributed between the central government and lower levels of government. State authority is divided among a wide range of actors, making politics less threatening and therefore encouraging joint problem solving. Devolution creates a fairer political ground, protects groups and individual human rights, establishes check and balances to central power and prevents political violence among rival groups.

The above remarks, nevertheless, point to the fact that what is required in lieu of the current crises roaring their ugly heads in the Nigerian state is simply and squarely devolution of powers from the Central government to the State and Local governments. This perception was captured in the statement made by Atiku Abubakar in Vanguard Editorial (May 31, 2016) while pointing out the significance of devolution of powers to nation's stability and development. Atiku notes that greater autonomy, power and resources for state and local authority provides the federation units with greater freedom and flexibility to address local issues for their priorities and peculiarities, reduce the premium placed on capturing power at the centre, reduce insecurity and promote healthy rivalry among the federating units.

\section{Conclusion and Recommendations}

The paper has established that what distinguishes a unitary form of political administration from a federal polity is that no level of government in a federation is wholly or continuously subordinate to the other. This clearly shows that what obtains in Nigeria is contrary to the norms and principles of a true federal system thus making it prone to all sorts of crisis and in stability. The crisis with Nigerian federalism is a man-made, and requires political will from political managers, as long as regional integration remains a stage where former independent entities have handed parts or all of their sovereignty over to a national body and integrated into a nation. The 
paper therefore concludes that for Nigeria's federalism to stand the test of time and overcome myriad problems endangering her corporate existence and entity, embracing the neo-federalism paradigm is inevitable.

In view of the foregoing, this paper recommends that there is urgent need for accelerating the emergent nature of different militant groups with immediate adoption of neo-federalism paradigm or model (devolution of powers) where the different ethnic groups will be truly represented with a view to engendering national integration, peace and stability, as well as getting governance closer to the hoi polloi. To achieve this, the adoption and implementation of recommendations of the 2014 Confab report by the current administration, is imperative. Moreover, the attitudes of both the leaders and the led towards governance needs to change. Also, immediate attention should be summoned towards solving socio-economic problems affecting the polity. There is the need for adequate provision of sustainable security at all levels of governance. More importantly is the visionary, dedicated and committed leaderships at all levels of government, with the ability to rule with utmost command of respect and authority, and to drive the economic blueprints of this great country towards providing social and basic amenities cum infrastructural needs for the vulnerable citizens. Above all, both the Federal and State governments should be more responsive and responsible to the plights of their people rather than the pursuit and achievement of their political goals.

\section{Acknowledgements}

This study was not supported by any research grant. We however, acknowledge the support of the various institutions especially Political Science Department, Ebonyi State University for conducive environment created for this research. We also acknowledge all the authorities whose works were cited in-text.

\section{References}

Adenikinju, A. (2016). The Nigerian economy: Current issues and strategic options. Nigerian Tribune, July 18. Retrieved from http://www.tribuneonlineng.com/nigerian-economy-current-issues-strategic-options/

Adetayo, O. (2016). 110 million Nigerians are poor, says Osinbajo. Punch, July 16. Retrieved from http://punchng.com/110-million-nigerians-poor-says-osinbajo/

Akinola, A. B., Adebisi, K. S., \& Oyewo, O. O. (2015). Leadership and democratic governance in Nigeria. Journal of Developing Country Studies, 5(6), 83-89.

Ali, A. D. (2013). Leadership and socioeconomic challenges in Nigeria. Singaporean Journal of Business Economics and Management Studies, 1(9), 1-8. https://doi.org/10.12816/0003789

Atiku, A. (2016). Restructuring Nigeria for greater national integration and democratic stability. Paper presented at the Late Gen. Usman Katsina Memorial Conference, at the Umaru Musa Yar'Adua Memorial Hall, Murtala Square, Kaduna, July 30.

Awofeso, O. (2014). Constitutional development in Nigeria: Historical and political analysis. Lagos: McGrace Publishers.

Bassey, A. O. (2012). A theoretical prognosis and analysis of federal balance in Nigeria, 1954-2013. Review of Arts and Humanities, 1(1), 51-65.

Dauda, K. O. (2017). Whistleblowing as anti-corruption strategy: Problems and prospects in Nigeria. Lapai International Journal of Public Administration, 1(1), 389-404.

Dickson, M., \& Asua, S. A. (2016). The politics of resource control in Nigeria: Agitation and innovation. International Journal of Politics and Good Governance, 7(2), 1-13.

Enu, D. B., Opoh, F. A., \& Bassey, P. E. (2017). Balancing the imbalances in the structure of Nigeria federalism: The civic educators' perspective. International Journal of Advanced Research in Public Policy, Social Development and Enterprise Studies, 2(1), 71-82.

Eze, R. C., Nkwede, J. O., \& Uwabunkonye, O. (2012). The controversy of federalism in governance in Nigeria: An appraisal. International Journal of Asian Social Science, 2(4), 441-447.

Falola, T., \& Heaton, M. M. (2008). A history of Nigeria. London: Cambridge University Press. https://doi.org/10.1017/CBO9780511819711

Friedrich, J. C. (1968). Trends of federalism in theory and practice. New York: Praeger.

Hancock, B., Ockleford, E., \& Windridge, K. (2009). An introduction to qualitative research. Nottingham and Sheffield: The NIHR RDS EM/YH.

Kapur, A. C. (2006). Principles of political science. New Delhi, India: S. Chand \& Co. Ltd. 
Lawal, M. A., \& Dauda, K. O. (2016). Islamic leadership paradigms: Universal remedy to bad leadership and sustainable democratic dispensation in Nigeria. ICSHER Journal, 2(2), 39-53.

Malendez, J. (2016). Elites and organised crime: Conceptual framework - elites. Insight Crime, March 23. Retrieved from http://www.insightcrime.org/investigations/elites-and-organised-crime-conceptual-frame work-elites/

McLean, I., \& McMillan, A. (2003). Oxford concise dictionary of politics. New York: Oxford University Press.

Muhammad, A. A. (2007). Federalism and political stability in Nigeria: Current peril and future hopes. Journal of Sustainable Development in Africa, 9(4), 187-210.

Nkwede, J. O. (2013). Federalism and state creation in Nigeria. African Journal of Politics and Administrative Studies, 6(1), 70-80.

Nkwede, J. O., Nkwali, T. B., \& Orga, J. (2013). Fiscal federalism and challenges of development in Nigeria: A search for remediation. Review of Public Administration and Management, 2(3), 121-132.

Odigbo, J. (2013). De-constructing decentralization and devolution of powers: Rethinking the functionality of local government system in Nigeria. IOSR Journal of Humanities and Social Science (IOSR-JHSS), 15(1), 37-43. https://doi.org/10.9790/0837-1513743

Ojo, E. O. (2009). Federalism and the search for national integration in Nigeria. African Journal of Political Science \& Intl. Relations, 3(9), 384-395.

Okotie, H. (2010). Evolution of Nigerian local government. Lagos: National Open University of Nigeria.

Osuntokun, A. (2016). Of corruption and federalism. This Daylive, June 10. Retrieved from https://www.thisdaylive.com/index.php/2016/06/10/of-corruption-and-federalism/

Toluwani, E. (2017). Less than 60 people decide Nigeria's fortune-Utomi. Punch, August 11. Retrieved from http://punchng.com/less-than-60-people-decide-nigerias-fortune-utomi/

Vanguard Editorial. (2016, May 31). We must renegotiate our union to make it strong-Atiku. Retrieved from https://www.vanguardngr.com/2016/05/we-must-renegotiate-our-union-to-make-it-strong-atiku/

Vanguard Editorial. (2017, June 30). Nigeria: What is restructuring. Retrieved from http://www.vanguardngr.com/2017/06/nigeria-what-is-restructuring/

Vile, M. J. C. (1961). The structure of American federalism. London: Oxford University Press.

Wheare, K. C. (1963). Federal government. London: Oxford University Press.

\section{Copyrights}

Copyright for this article is retained by the author(s), with first publication rights granted to the journal.

This is an open-access article distributed under the terms and conditions of the Creative Commons Attribution license (http://creativecommons.org/licenses/by/4.0/). 